Short Review

\section{Chlorhexidine and oral cancer: A short review}

\section{Shrivardhan R Kalghatgi*, Mahesh R Khairnar² and Tanushri Dalvi²}

\author{
${ }^{1}$ Associate Professor, Department of Public Health Dentistry, Bharti Vidyapeeth (Deemed to be \\ University) Dental College and Hospital, Sangli, India \\ ${ }^{2}$ Assistant Professor, Department of Public Health Dentistry, Bharti Vidyapeeth (Deemed to be \\ University) Dental College and Hospital, Sangli, India
}

Owing to the ever westernizing lifestyles in developing countries like India, the escalation of oral cancer patients are in need of urgent plan of action. With tobacco being the commonest cause for causation of oral cancer, Global Adult Tobacco Survey, 2016-17 revealed that almost 28\% of whole population of India is consuming tobacco in either smoking or smokeless form. With these increasing numbers, the expected death toll to be expected to touch 1-2 million mark by the year 2035 [1].

Although, the current Onco-medicine fraternity excels in rendering care to oral cancer patients in the form of surgeries, chemotherapy and radiation-therapy. Often, these treatment modalities impart some unwanted adverse effects like, docetaxel (DCT) is known for its hepatotoxicity [2,3] whereas, one of the commonly used cisplatin (CIS) presents with nephrotoxicity, neurotoxicity, bone marrow suppression and vomiting $[4,5]$. Literature suggests of many non conventional medicaments being tested in past for their anti onco-genic effect, where few being effective and others being questionable ones. Chlorhexidine being one among them showing some how promising anti onco-genic activity with feeble amount of studies being conducted in past.

Chlorhexidine, one of the most commonly prescribed mouthrinse in the field of dentistry, with varying concentrations of $0.12 \%$ and $0.2 \%$ concentrations. Although, apart from being broad spectrum antibiotic, its capability to dismantle the protein - protein bond between anti - apoptotic Bcl-2 family protein $\mathrm{Bcl}-\mathrm{x}_{\mathrm{L}}$ and its pro - apoptotic binding partners [6]. The current study was conducted on three cell lines of squamous cell carcinoma (SCC-4, SCC-9, SCC -15) and two pharynx carcinoma cell lines (FaDu and Detroit 562). The compounds induced apoptosis through mitochondria dependent apoptotic pathway in oral tumour cell lines. Another study conducted to assess the similar anti - oncogenic activites of chlorhexidine mouthrinse along with cranberry [7]. It was evident from results that, with increasing concentrations of chlorhexidine mouthrinse, there was increase in mean percent growth

\author{
More Information \\ *Address for Correspondence: Dr. Shrivardhan \\ Kalghatgi, Associate Professor, Department \\ of Public Health Dentistry, Bharti Vidyapeeth \\ (Deemed to be University) Dental College and \\ Hospital, Sangli, India, \\ Email: drshriphd@gmail.com \\ Submitted: 10 February 2020 \\ Approved: 17 February 2020 \\ Published: 18 February 2020 \\ How to cite this article: Kalghatgi SR, Khairnar \\ MR, Dalvi T. Chlorhexidine and oral cancer: A \\ short review. Arch Cancer Sci Ther. 2020; 4: \\ 001-002. \\ DOI: dx.doi.org/10.29328/journal.acst.1001012 \\ Copyright: ( 2020 Kalghatgi SR, et al. This
is an open access article distributed under
the Creative Commons Attribution License,
which permits unrestricted use, distribution,
and reproduction in any medium, provided the
original work is properly cited. \\ Check for updates \\ OPEN ACCESS
}

inhibition. The authors concluded saying, chlorhexidine has showed both anti cancerous as well as anti bacterial activity required to tackle common oral infections, part of common anti cancer therapy. Fernando Martínez-Pérez et al (2019) conducted study, where antitumor activity of Lipophilic Bismuth Nanoparticles (BisBAL NPs) and chlorhexidine on human squamous cell carcinoma was assessed using energy dispersive $\mathrm{X}$ - ray spectroscopy in conjunction with scanning electron microscopy (EDS-SEM). Study revealed, BisBAL NPs and chlorhexidine both showed cell growth inhibition on both cancer cell line (CAL-27) and human gingival fibroblasts (HGFs). Although, chlorhexidine showed non specific cytotoxicity for both tumoral and non tumoral control cells. The suggestive mechanism of action might be loss of cell membrane integrity [8].

Although Eliot MN (2013) conducted study, to assess the risk of head and neck squamous cell carcinoma secondary to use of alcohol containing and non alcoholic mouthwashes including chlorhexidine. The study was concluded with an assumption based on chlorhexidine mouthwash alters the oral flora [9], thus resulting in increasing risk exponentially through diverse change in oral bacteria and altered immune response with contribution towards genesis or promotion of cancer [10]. On the contrary, alcohol consumption and smoking are predisposing factors towards upper digestive tract cancer. The main causative factor being the first metabolite of alcohol, acetaldehyde. And much higher levels 
are derived from oral bacteria and thus, same can be altered in favour through usage of chlorhexidine mouthwash, to avoid excessive production of acetaldehyde intra orally.

In conclusion, chlorhexidine mouthwash has been into dental practice since long and the role it plays in either ways has to be assessed by a multi dimensional study with cell lines including that of control to derive better compared conclusions

\section{References}

1. Bray F, Ren JS, Masuyer E, Ferlay J. Global estimates of cancer prevalence for 27 sites in the adult population in 2008. Int $\mathrm{J}$ Cancer. 2013; 132: 1133-1145.

PubMed: https://www.ncbi.nlm.nih.gov/pubmed/22752881

2. Yared JA, Tkaczuk KH. Update on taxane development: new analogs and new formulations. Drug Des Devel Ther. 2012; 6: 371-384. PubMed: https://www.ncbi.nlm.nih.gov/pubmed/23251087

3. Wang Z, Liang $X, Y u$ J, Zheng $X$, Zhu $Y$, et al. Non-genetic risk factors and predicting efficacy for docetaxel-drug-induced liver injury among metastatic breast cancer patients. J Gastroenterol Hepatol. 2012; 27: 1348-1352.

PubMed: https://www.ncbi.nlm.nih.gov/pubmed/22432938

4. Kilic U, Sahin K, Tuzcu M, Basak N, Orhan C, et al. Enhancement of cisplatin sensitivity in human cervical cancer: epigallocatechin-3-gallate. Front Nutr. 2015; 1: 28.

PubMed: https://www.ncbi.nlm.nih.gov/pubmed/25988128
5. Kitagawa R, Katsumata N, Shibata T, Kamura T, Kasamatsu T, et al. Paclitaxel plus carboplatin versus paclitaxel plus cisplatin in metastatic or recurrent cervical cancer: the open-label randomized phase III trial JCOG0505. J Clin Oncol. 2015; 33: 2129-2135.

PubMed: https://www.ncbi.nlm.nih.gov/pubmed/25732161

6. Gräber M, Hell M, Gröst C, Friberg A, Sperl B, et al. Oral disinfectants inhibit protein-protein interactions mediated by the anti-apoptotic protein $\mathrm{Bcl}-\mathrm{xL}$ and induce apoptosis in human oral tumor cells. Angew Chem Int Ed Engl. 2013; 52: 4487-4491.

PubMed: https://www.ncbi.nlm.nih.gov/pubmed/23512547

7. Khairnar MR, Wadgave $U$, Jadhav $H$, Naik R. Anticancer activity of chlorhexidine and cranberry extract: an in-vitro study. J Exp Ther Oncol. 2018; 12: 201-205.

PubMed: https://www.ncbi.nlm.nih.gov/pubmed/29790310

8. Martínez-Pérez F, García-Cuellar CM, Hernandez-Delgadillo $\mathrm{R}$, Zaragoza-Magaña V, Sánchez-Pérez $Y$, et al. Comparative Study of Antitumor Activity between Lipophilic Bismuth Nanoparticles (BisBAL NPs) and Chlorhexidine on Human Squamous Cell Carcinoma. J Nanomaterials. 2019.

9. Radford JR, Beighton D, Nugent Z, Jackson RJ. Effect of use of $0.05 \%$ cetylpyridinium chloride mouthwash on normal oral flora. J Dent. 1997; 25: $35-40$.

PubMed: https://www.ncbi.nlm.nih.gov/pubmed/9080738

10. Eliot MN, Michaud DS, Langevin SM, McClean MD, Kelsey KT. Periodontal disease and mouthwash use are risk factors for head and neck squamous cell carcinoma. Cancer Causes Control. 2013; 24: $1315-1322$.

PubMed: https://www.ncbi.nlm.nih.gov/pubmed/23568534 